\title{
Intragastric Penetration of the Connecting Tube After Laparoscopic Adjustable Gastric Banding
}

\section{Penetração Intra-Gástrica do Tubo Conector de Banda Gástrica Colocada por Via Laparoscópica}

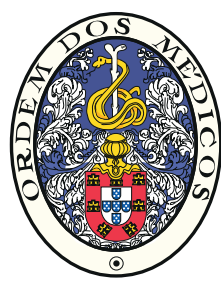

Samuel COSTA $\otimes^{1}$, Artur MACHADO ${ }^{1}$, Bruno GONÇALVES ${ }^{1}$, José MAIA DA COSTA², Raquel GONÇALVES ${ }^{1}$ Acta Med Port 2017 Apr;30(4):338-338 - https://doi.org/10.20344/amp.7434

Keywords: Gastroplasty; Laparoscopy; Postoperative Complications

Palavras-chave: Complicações Pós-Operatórias; Gastroplastia; Laparoscopia

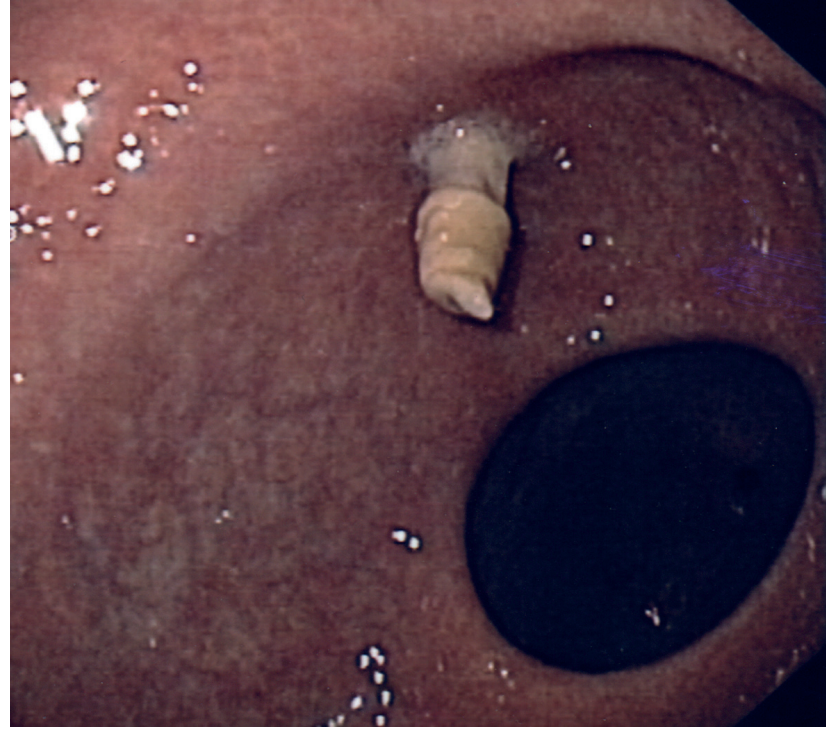

Figure 1 - Esophagogastroduodenoscopy

A 37-years-old woman with obesity grade II, hypertension and dyslipidemia was submitted to laparoscopic adjustable gastric banding (LAGB) in 2009. In 2013, because of a port site infection, the port was removed. Three months later she went to the emergency department for epigastric pain and vomiting. The abdominal computed tomography scan showed gastric distention with liquid/air and the esophagogastroduodenoscopy gastric band and connecting

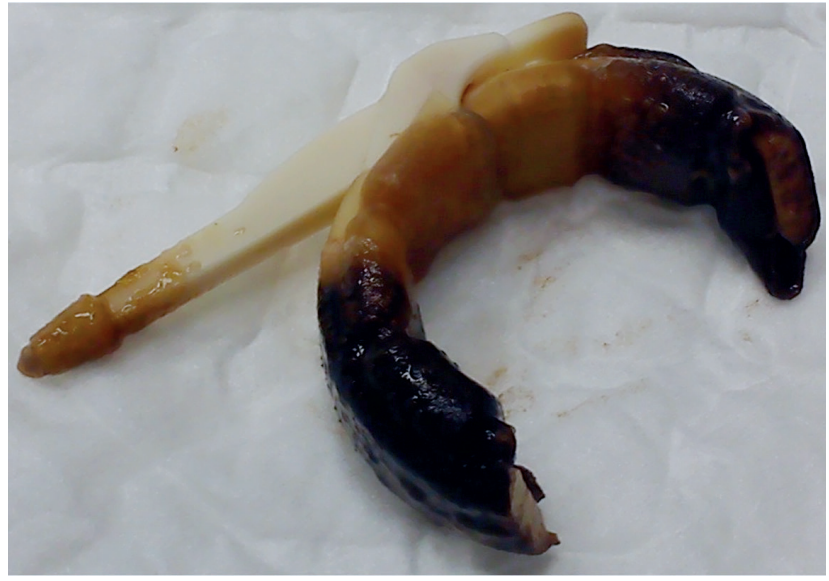

Figure 2 - Gastric band and connecting tube

tube migration (Fig. 1).

Long-term complications resulted in a decrease of LAGB popularity. Migration of the gastric band occurs in up to $11 \% .^{1}$ To the best of our knowledge this is the first case of connecting tube migration into the gastric antrum. We achieved endoscopic removal of the band and connecting tube without complications (Fig. 2). There is only one report of connecting tube migration to the gastric fundus and was managed surgically. ${ }^{2}$

The endoscopic removal of migrated gastric bands is a feasible (85\% success rate), low complications $(5.8 \%$ : mainly symptomatic pneumoperitoneum) procedure. ${ }^{3}$

\section{REFERENCES}

1. Westling A, Bjurling K, Ohrvall M, Gustavsson S. Silicone adjustable gastric banding: disappointing results. Obes Surg. 1998;8:467-74.

2. Dogan ÜB, Akin MS, Yalaki S, Akova A, Yilmaz C. Endoscopic management of gastric band erosions: a 7-year series of 14 patients. Can J Surg. 2014;57:106-11.

3. Neto MP, Ramos AC, Campos JM, Murakami AH, Falcão M, Moura EH, et al. Endoscopic removal of eroded adjustable gastric band: lessons learned after 5 years and 78 cases. Surg Obes Relat Dis. 2010;6:423-7. 